\title{
Identification of Genetic Markers in Olive Linked to Olive Leaf Spot Resistance and Susceptibility
}

\author{
Genet Teshome Mekuria, Graham Collins, ${ }^{1}$ and Margaret Sedgley \\ Department of Horticulture, Viticulture and Oenology, Adelaide University, Waite Campus, Glen Osmond, \\ South Australia 5064, Australia
}

\author{
Shimon Lavee \\ Institute of Horticulture, The Volcani Center, Bet-Dagan, Israel
}

ADDITIONAL INDEX WORDS. Olea europaea, Spilocea oleaginea, bulked segregant analysis, DNA marker

\begin{abstract}
Olive leaf spot is a disease of olive (Olea europaea L.) caused by the fungal pathogen, Spilocea oleaginea Cast. Progeny derived from crosses among susceptible, resistant, and semiresistant parental lines were assessed in the field for 8 years and classified as either resistant or susceptible. DNA from some of the progeny of this segregating population was used to identify molecular markers linked to olive leaf spot disease using the randomly amplified polymorphic DNA (RAPD) technique and bulked segregant analysis (BSA). Two DNA bulks were constructed, each containing 13 progeny showing either resistance or susceptibility for the disease, and screened for polymorphisms using 100 primers. One primer produced two polymorphic bands, one of $\approx 700$ base pairs (bp) from the susceptible bulk and the other of $\approx 780 \mathrm{bp}$ from the resistant bulk. The $780 \mathrm{bp}$ marker appeared in $70.6 \%$ of the segregating progeny and $100 \%$ of parents showing resistance to leaf spot disease, while the $700 \mathrm{bp}$ marker appeared in $47.1 \%$ of the segregating progeny and $100 \%$ of the parents showing susceptibility. These markers can be used as screening tools in olive improvement programs.
\end{abstract}

Olive leaf spot, peacock spot, peacock eye, and bird's eye spot are alternative names for the disease incited by the pathogen, Spilocea oleaginea (syn. Cycloconium oleaginum Cast.) (Ogawa and English, 1991; Teviotdale, 1994). It is the most important leaf disease of olive (Olea europea) in many countries around the Mediterranean basin as well as in California, South Africa, South America, and Australia (Shabi et al., 1994). The pathogen attacks mainly leaves, producing lesions and circular spots on the upper surfaces, but in rare cases fruits and fruit stems may also be attacked. Some lesions develop a yellow halo that looks like the eye spot on the tail feathers of a peacock, hence the names peacock spot and bird's eye spot (Teviotdale, 1994), whereas others are small spots that are usually black. Infestation is associated with rainy periods and is a particularly significant problem in damp, low lying areas during wet years. It causes extensive defoliation that results in a marked reduction in both flower bud differentiation, and fruit set in subsequent years (Shabi et al., 1994; Teviotdale, 1994). A complete loss of yield of some sensitive cultivars can occur under extreme inductive climatic conditions.

Susceptibility to infection by $S$. oleaginea varies among cultivars. For example, in California, Sutter (1994) found that the order of resistance among several cultivars from highest to lowest was 'Sevillano', 'Manzanillo', 'Ascolano', 'Barouni', and 'Mission'. Screening progeny for phenotypic traits in a breeding program involving large scale, long-term selection takes many years. The problem is often exacerbated for tree fruits, such as olive, because phenotypic expression can be influenced by environmental conditions (Shabi et al., 1994). On the other hand, the juvenile leaves of olive are more sensitive to S. oleaginea than mature ones, so selection for resistance can be started in the second year after planting (Lavee, 1990).

Received for publication 27 June 2000. Accepted for publication 28 Dec. 2000. We thank Yair Many for maintenance of the breeding plots. G.T.M was supported by an Australian Post Graduate Award Scholarship. The research was supported by the Australian Research Council. The cost of publishing this paper was defrayed in part by the payment of page charges. Under postal regulations, this paper therefore must be hereby marked advertisement solely to indicate this fact. ${ }^{1}$ Corresponding author.
Michelmore et al. (1991) reported the use of bulked segregant analysis (BSA) to identify genetic markers linked to specific genes of interest. The procedure has been used successfully in many studies, including markers for freestone in peach [Prunus persica (L.) Batsch (Peach Group)] (Warburton et al., 1996), the Fom 2 gene for resistance to fusarium wilt (Fusarium oxysporum Schlechtend.) in musk melon [Cucumis melo L. (Reticulatus Group)] (Wechter et al., 1995), and glaucousness of leaves in cider gum [Eucalyptus gunnii J.D. Hook (series Viminales)] (Wirthensohn et al., 1999). In the present study the randomly amplified polymorphic DNA(RAPD) polymerase chain reaction (PCR) technique, which has already been applied to the identification of olives (Fabbri et al., 1995; Mekuria et al., 1999; Wiesman et al., 1998) was used in conjunction with BSA to identify a genetic marker linked to resistance to olive leaf spot using a segregating population from a breeding program at the Volcani Center, Bet-Dagan, Israel.

\section{Materials and Methods}

SEgREgATING POPULATION. A breeding program for resistance to S. oleaginea has been underway at the Volcani Center, Bet-Dagan, Israel, since the early 1980s. Trees are grown under irrigation in a maritime subtropical climate with predominantly winter rain, and hot summers with high relative humidity ( $75 \%$ to $85 \%)$. The natural incidence of olive leaf spot is high, and based on the occurrence of symptoms in the field, the progeny of the breeding program are designated as resistant, semiresistant (occasional infection), or susceptible (regular infection).

The tree used as the initial parent in the breeding program for olive leaf spot resistance was selected from 17 trees, all showing low susceptibility to $S$. oleaginea, that were growing in an orchard known to be infected with the disease (Lavee et al., 1999). In 1980, it was self-pollinated and the progeny were grown in the original infected area.

Five of the progeny, designated MAS-5, MAS-21, MAS-27, MAS-29, and MAS-30, were selected (Table 1) and observed over a period of 20 years under infective conditions. Four of the trees that showed no symptoms were designated as resistant, and were 
Table 1. Segregation of olive leaf spot resistance based on field observations, and detection of markers using primer OPA11 (700 and 780 bp).

\begin{tabular}{|c|c|c|c|c|}
\hline Genotype & $\begin{array}{l}\text { Used in bulk } \\
\text { DNA samples }\end{array}$ & $\begin{array}{c}\text { Field } \\
\text { response }^{\mathrm{z}}\end{array}$ & $700 \mathrm{bp}$ & $780 \mathrm{bp}$ \\
\hline \multicolumn{5}{|l|}{ Parents } \\
\hline \multicolumn{5}{|l|}{ Male } \\
\hline Barnea & & R-S (1) & + & - \\
\hline Manzanillo & & R-S (2) & + & - \\
\hline Muhasan & & S & + & - \\
\hline Souri & & $\mathrm{S}$ & + & - \\
\hline \multicolumn{5}{|c|}{ Female (20 years field observation) } \\
\hline MAS-21 & & $\mathrm{R}$ & - & + \\
\hline MAS-27 & & $\mathrm{R}$ & - & + \\
\hline MAS-29 & & $\mathrm{R}$ & - & + \\
\hline MAS-30 & & $\mathrm{R}$ & - & + \\
\hline MAS-5 & & R-S (1) & + & - \\
\hline \multicolumn{5}{|c|}{ Crosses (8 years field observation) } \\
\hline \multicolumn{5}{|c|}{ MAS-30 x Barnea } \\
\hline BD3-73 & $\mathrm{B}$ & $\mathrm{R}$ & - & + \\
\hline BD3-76 & $\mathrm{B}$ & $\mathrm{R}$ & + & + \\
\hline BD3-82 & B & $\mathrm{R}$ & - & + \\
\hline BD3-74 & $\mathrm{B}$ & $\mathrm{S}$ & - & - \\
\hline BD3-77 & $\mathrm{B}$ & $\mathrm{S}$ & - & - \\
\hline BD3-78 & $\mathrm{B}$ & $\mathrm{S}$ & + & - \\
\hline \multicolumn{5}{|c|}{ MAS-27 x Manzanillo } \\
\hline BD2-258 & $\mathrm{B}$ & $\mathrm{R}$ & - & + \\
\hline BD2-260 & $\mathrm{B}$ & $\mathrm{R}$ & - & + \\
\hline BD2-256 & $\mathrm{B}$ & $\mathrm{S}$ & + & - \\
\hline BD2-257 & $\mathrm{B}$ & $\mathrm{S}$ & + & - \\
\hline \multicolumn{5}{|c|}{ MAS-30 x Muhasan } \\
\hline BD3-137 & $\mathrm{B}$ & $\mathrm{R}$ & - & - \\
\hline BD3-147 & $\mathrm{B}$ & $\mathrm{R}$ & - & + \\
\hline BD3-143 & $\mathrm{B}$ & $\mathrm{S}$ & - & - \\
\hline BD3-149 & $\mathrm{B}$ & $\mathrm{S}$ & - & - \\
\hline \multicolumn{5}{|l|}{ MAS-29 x Souri } \\
\hline BD2-265 & $\mathrm{B}$ & $\mathrm{R}$ & + & + \\
\hline BD2-268 & B & $\mathrm{R}$ & - & $--^{\mathrm{y}}$ \\
\hline BD2-266 & & $\mathrm{R}$ & - & + \\
\hline BD2-269 & B & $\mathrm{S}$ & + & + \\
\hline BD2-275 & $\mathrm{B}$ & $\mathrm{S}$ & + & + \\
\hline \multicolumn{5}{|l|}{ MAS-30 x Souri } \\
\hline BD3-108 & $\mathrm{B}$ & $\mathrm{R}$ & - & - \\
\hline BD3-105 & B & $\mathrm{S}$ & + & - \\
\hline BD3-111 & & $\mathrm{S}$ & - & + \\
\hline \multicolumn{5}{|c|}{ MAS-5 x Manzanillo } \\
\hline BD3-88 & B & $\mathrm{R}$ & + & - \\
\hline BD3-96 & $\mathrm{B}$ & $S$ & - & - \\
\hline BD3-89 & & $\mathrm{S}$ & + & - \\
\hline BD3-95 & & $\mathrm{S}$ & + & - \\
\hline \multicolumn{5}{|c|}{ MAS-21 x Manzanillo } \\
\hline BD3-156 & $\mathrm{B}$ & $\mathrm{R}$ & - & + \\
\hline BD3-165 & $\mathrm{B}$ & $\mathrm{R}$ & - & + \\
\hline BD3-168 & & $\mathrm{R}$ & + & - \\
\hline BD3-160 & $\mathrm{B}$ & $\mathrm{S}$ & - & + \\
\hline BD3-164 & $\mathrm{B}$ & $\mathrm{S}$ & - & + \\
\hline \multicolumn{5}{|l|}{ Selfed MAS-29 } \\
\hline BD2-281 & & $\mathrm{R}$ & + & + \\
\hline BD2-284 & & $\mathrm{R}$ & - & + \\
\hline BD2-285 & & $\mathrm{R}$ & - & - \\
\hline
\end{tabular}

$\overline{{ }^{\mathrm{Z}} \mathrm{R}}=$ resistant; $\mathrm{S}=$ highly susceptible; $\mathrm{R}-\mathrm{S}$ = semiresistant: 1 , slightly susceptible, 2 , moderately susceptible; $\mathrm{B}=$ individuals used in the bulk; (+) marker present; (-) marker absent.

yRecently showed infection. 
confirmed resistant under laboratory conditions (Lavee et al., 1999). The tree, MAS-5, showed occasional slight infection, and was designated semiresistant. The five trees were crossed as female parents with 'Barnea', 'Manzanillo', 'Muhasan', and 'Souri', all of which exhibit different degrees of susceptibility to $S$. oleaginea. 'Barnea' is the most resistant and 'Souri' is the least resistant (Lavee et al., 1999).

LEAF SAMPLES. Trees that never showed infection to leaf spot over a 20 year period (in the case of the female parents), or 8 years (for the progeny from the controlled crosses), were designated as resistant. Leaves from the following plants were used: five female parents, MAS-21, MAS-27, MAS-29, MAS-30 (all resistant), and MAS-5(semiresistant); fourmale parents, 'Barnea' (B), 'Manzanillo' (M) (both semiresistant), 'Muhasan' (Mu) and 'Souri' (S) (both susceptible), and 26 progeny derived from the following parental combinations: MAS-30 x S, MAS-30 x Mu, MAS-30 x B, MAS-29 x S, MAS-27 x M, MAS-21 x M, and MAS-5 x M (Table 1).

DNA ISOLATION AND PREPARATION OF BULKED DNA SAMPLES. DNA was extracted by the protocol of Mekuria et al. (1999). Two bulked DNA samples were constructed for analysis according to Michelmore et al. (1991). Each bulk consisted of a mixture of equal amounts of DNA from 13 individuals, one bulk from those designated as resistant, and the other bulk from those designated as susceptible. Progeny from the same parental combinations were represented in each of the two DNA bulks (Table 1).

PCr AND Gel Electrophoresis. The two DNA bulks were subjected to RAPD-PCR using a total of 40 ng of genomic DNA, 1.5 $\mathrm{mm} \mathrm{MgCl}_{2}, 0.25 \mu \mathrm{M}$ 10-mer oligodeoxynucleotide primer (Operon Technologies, Almeda, Calif.), $200 \mu \mathrm{m}$ each of dGTP, dATP, dTTP, and dCTP, $1 \times$ PCR buffer $(10 \mathrm{~mm}$ Tris $\mathrm{HCl}, \mathrm{pH} 8.3,50 \mathrm{~mm} \mathrm{KCl}$, $0.001 \%(\mathrm{w} / \mathrm{v})$ gelatine) and 1 unit Taq DNA polymerase (GIBCOBRL, Life Technologies, Inc., Gaithersburg, Md.) in $20 \mu \mathrm{L}$, and overlaid with two drops of mineral oil. DNA amplification was performed in a thermocycler (Programmable Thermal Controller, MJ Research, Inc., Watertown, Mass.) according to the following program: $2 \mathrm{~min}$ at $95^{\circ} \mathrm{C}$ for initial strand separation, followed by 39 cycles of $1 \mathrm{~min}$ at $95^{\circ} \mathrm{C}, 10 \mathrm{~s}$ at $50^{\circ} \mathrm{C}, 15 \mathrm{~s}$ at $45^{\circ} \mathrm{C}, 20 \mathrm{~s}$ at $40^{\circ} \mathrm{C}, 1 \mathrm{~min}$ at $35^{\circ} \mathrm{C}$, $30 \mathrm{~s}$ at $45^{\circ} \mathrm{C}, 1 \mathrm{~min} 45 \mathrm{~s}$ at $72^{\circ} \mathrm{C}$, with a final extension step of $5 \mathrm{~min}$ at $72^{\circ} \mathrm{C}$ (Collins and Symons, 1993). A total of 100 random decamer primers (OPA, OPB, OPD, OPF, and OPZ kits) (Operon Technologies, Almeda, Calif.) were screened for polymorphism between the resistant bulk and the susceptible bulk.

Amplification fragments were separated on $1.5 \%$ (w/v) agarose gels (Seakem GTG agarose, FMC, BioProducts, Rockland, Maine) in $1 \times$ TBE buffer $(89 \mathrm{~mm}$ Tris $\mathrm{HCl}, 89 \mathrm{~mm}$ boric acid, and $5 \mathrm{~mm}$ EDTA) at $80 \mathrm{~mA}$. A 100 base pair (bp) DNA ladder (DMW-100M, GeneWorks, Adelaide, Australia) was used as the molecular weight standard. After electrophoresis, gels were stained with ethidium bromide $\left(0.5 \mu \mathrm{g} \cdot \mathrm{mL}^{-1}\right)$, destained with distilled water, and the digital image was scanned directly under ultraviolet (UV) light using the Tekcap computer program (version 1.0. Tekram Corp. Fremont, Calif.), captured using PaintShop Pro (version 5.00, Jasc Software, Inc., Minneapolis), and photographed under UV light using Polaroid 667 film (Polaroid, Hertfordshire, U.K.)

CONFIRMATION OF MARKER LINKED TO OLIVE SPOT. When a consistent polymorphism was found between the two bulks, it was tested for linkage to leaf spot resistance by examining the PCR products obtained from all parents, all 26 progeny that comprised the bulks, and a further eight samples of DNA extracted from other progeny. The same primers and PCR conditions that generated the unique fragment were used for all tests. For enhanced resolution, the products were separated on $6 \%$ polyacrylamide (Accugel 40\% 19 acrylamide : 1 bisacrylamide, Kimberly Res. Atlanta., Ga) as described in Collins and Symons (1993).

STATISTICAL ANALYSIS. The recombination frequency between the molecular markers and the genes conferring either resistance or susceptibility to $S$. oleaginea were calculated as $\mathrm{Rf}=\mathrm{Rm}+\mathrm{SM} / \mathrm{n}$, and $\mathrm{Rf}=\mathrm{Sm}+\mathrm{RM} / \mathrm{n}$ respectively, where $\mathrm{Rf}=$ recombination frequency, and Rm, SM, Sm, RM, and $\mathrm{n}$ are the number of resistant recombinants without the resistant marker, susceptible recombinants with the resistant marker, susceptible recombinants without the susceptible marker, resistant recombinants with the susceptible marker, and total number of individuals respectively (Yang and Krüger, 1994). The observed data was fitted to the expected data using chi-square analysis (Statistica for Windows Release 5.1, StatSoft Inc., Tulsa, Okla.).

\section{Results}

DNA from two bulked samples, each containing 13 progeny of the segregating population designated as either resistant or susceptible to leaf spot, was used as a template to identify a RAPD marker linked to olive leaf spot. A total of 100 random 10-mer oligonucleotide primers were used to screen the two bulks for polymorphisms. One primer, OPA11 (5' CAATCGCCGT 3’), generated two polymorphisms in the PCR products, one of $\approx 780 \mathrm{bp}$ with the resistant bulk, and the other of $\approx 700 \mathrm{bp}$ with the susceptible bulk (Fig. 1). The presence of these polymorphisms was confirmed in three separate $\mathrm{PCR}$ reactions.

To test the linkage of the RAPD markers to olive leaf spot resistance, DNA prepared from 43 individuals from the breeding program was subjected to the same PCR conditions as the bulked DNA. The individuals included the nine parents, and the 26 progeny used to prepare the two DNA bulks (Table 1).

A polymorphic band of $\approx 780 \mathrm{bp}$, produced by primer OPA11,

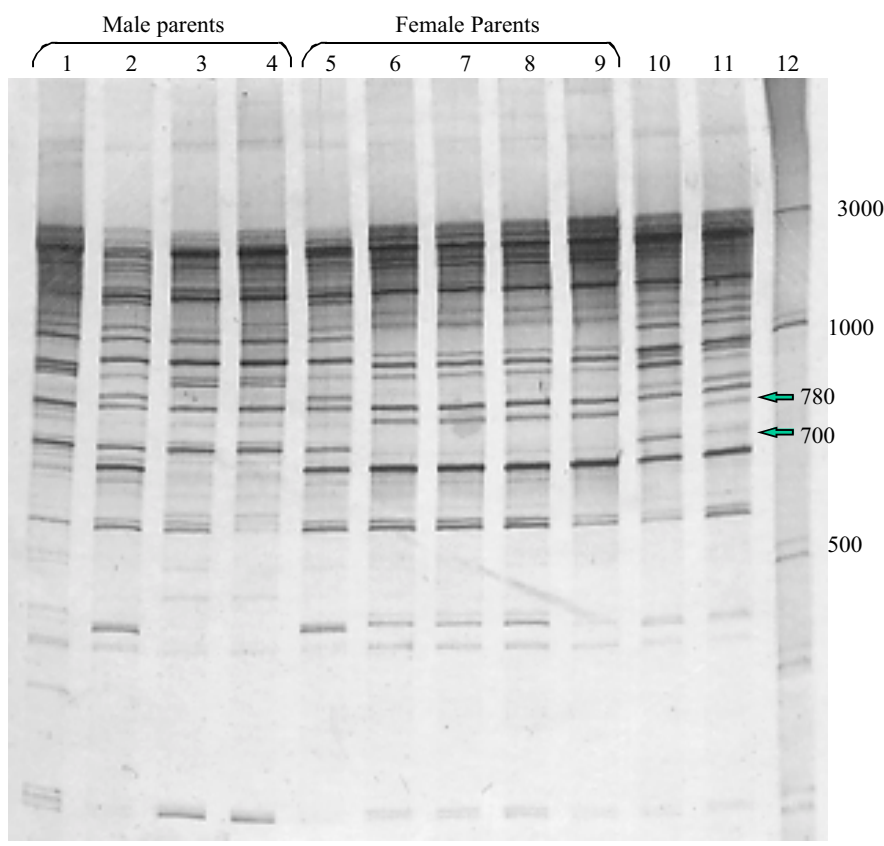

Fig. 1. Polymorphism at 700 and 780 bp (arrows) between the two bulks and parents, with primer OPA11. Lane 1: 'Souri' (susceptible); lane 2: 'Muhasan' (susceptible); lane 3: 'Manzanillo' (semiresistant); lane 4: 'Barnea' (semiresistant); lane 5: MAS-5 (semiresistant); lane 6: MAS-30; lane 7: MAS21; lane 8: MAS-27; lane 9: MAS-29 (all resistant); lane 10: susceptible bulk; lane 11: resistant bulk; lane 12: 100 bp DNA ladder. 
Table 2. Recombination frequencies for the 780 and 700 bp markers, and observed and expected numbers of segregating progeny.

\begin{tabular}{|c|c|c|c|c|c|}
\hline \multirow{2}{*}{$\begin{array}{l}\text { Genetic } \\
\text { marker }\end{array}$} & \multicolumn{4}{|c|}{ Progeny no. ${ }^{\mathrm{z}}$} & \multirow{2}{*}{$\begin{array}{c}\text { Recombination } \\
\text { frequency }\end{array}$} \\
\hline & $\mathrm{RM}$ & $\mathrm{Rm}$ & SM & $\mathrm{Sm}$ & \\
\hline $780 \mathrm{bp}$ & 12 & 5 & 5 & 12 & 0.29 \\
\hline Expected & 17 & 0 & 0 & 17 & \\
\hline 700 bp & 5 & 12 & 8 & 9 & 0.41 \\
\hline Expected & 0 & 17 & 17 & 0 & \\
\hline
\end{tabular}

${ }^{\mathrm{z}} \mathrm{R}=$ field resistant, $\mathrm{S}=$ field susceptible, $\mathrm{M}=$ marker present, $\mathrm{m}=$ marker absent.

was found to be closely linked to leaf spot resistance. Four of the resistant parents, and 12 of the 17 resistant progeny from the segregating population tested showed the marker band. It was present also in five of the 17 susceptible progeny tested, but not in any of the susceptible parents.

The polymorphic band produced from the susceptible bulk at $\approx 700 \mathrm{bp}$ was present in all of the susceptible parents, and 8 of the 17 susceptible progeny of the segregating population tested. It was present also in five of the 17 resistant progeny, but absent in the resistant parents. Table 2 shows the number of progeny segregating for resistance or susceptibility under field conditions and showing the presence or absence of the two molecular markers. Chi-square analysis showed that the numbers of segregating progeny did not vary from the expected values at $P \leq 0.05$.

\section{Discussion}

Two molecular markers each linked to the expression of resistance or susceptibility to olive leaf spot were identified by the RAPD-PCR technique, in conjunction with BSA, using primer OPA-11. One marker was $\approx 780 \mathrm{bp}$ and occurred in $70.6 \%$ of the resistant segregating population (field evaluated for 8 years), and $100 \%$ of the resistant parents (field evaluated for 20 years). For the combined populations tested, the band was present in $76.2 \%$ of resistant individuals, and absent in $77.3 \%$ of susceptible individuals. This is the first report of a molecular marker linked to resistance to olive leaf spot disease.

Of the 34 individuals examined for the molecular markers (Table 1), 17 showed resistance and 17 showed susceptibility when tested under field conditions (BD2-268 recently showed susceptibility). These 34 individuals were derived from eight different crosses and therefore conclusions cannot be drawn regarding a genetic model for resistance. However, Lavee et al. (1999) suggest that resistance is recessive. Chi-square analysis of the data in Table 2 showed that the expected segregation of individuals was not significantly different from the observed values. Based on this limited data set, the recombination frequencies suggest that the 780 and $700 \mathrm{bp}$ markers are 29 and $41 \mathrm{cM}$ distant from the gene, respectively.

Individuals that were classified as semiresistant to the disease did not produce the $780 \mathrm{bp}$ marker. Thus, no segregation was expected in the progeny derived from the cross between MAS-5 X'Manzanillo' because both lack the marker for resistance, although both are designated as semiresistant.

A second marker of $\approx 700 \mathrm{bp}$ was present in $59.1 \%$ of susceptible individuals and absent in $76.2 \%$ of resistant individuals. When the presence and/or absence of both markers was applied to all parents and progeny, $67.4 \%$ of the population could be designated as resistant and the same proportion as susceptible.

Discrepancies between the presence or absence of markers and the field data can be attributed to three reasons. Firstly, these markers identify areas close to the genes of interest rather than the genes themselves. The $780 \mathrm{bp}$ marker was more tightly linked to resistance than was the $700 \mathrm{bp}$ marker to susceptibility and will be more useful in the breeding program. Secondly, the results found for the $780 \mathrm{bp}$ molecular marker were $100 \%$ reproducible for the DNA from parental trees, and this finding was consistent with field observations over a 20-year period. However, in some progeny of the segregating population, a change in the level of resistance through time was observed. For example, BD2-268 was designated as resistant until it recently displayed disease symptoms. No RAPD marker linked to resistance to leaf spot was detected for this genotype. In addition, some trees that showed field resistance produced a susceptible response in laboratory tests (Lavee et al., 1999). This result suggests that if selection for resistance to olive leaf spot is made too early by field evaluation, there is a chance of falsely rating a plant as resistant. Thirdly, the phenotypic expression of resistance or susceptibility can be influenced by the environment, and hence some individuals may escape infection even when they are susceptible (Yang and Krüger, 1994). This emphasizes the importance of using molecular markers for early screening in breeding programs.

\section{Literature Cited}

Collins, G.G. and R.H. Symons. 1993. Polymorphism in grapevine DNA detected by the RAPD PCR technique. Plant Mol. Biol. Rptr. 11:105-112.

Fabbri, A., J.I. Hormaza, and V.S. Polito. 1995. Random amplified polymorphic DNA analysis of olive (Olea europaea L.) cultivars. J. Amer. Soc. Hort. Sci. 120:538-542.

Lavee, S. 1990. Aims, methods and advances in breeding of new olive (Olea europaea L.) cultivars. Acta Hort. 286:23-36.

Lavee, S., H. Harshemesh, A. Haskal, V. Meni, M. Wodner, A. Ogrodovich, B. Avidan, Z. Wiesman, N. Avidan, and A. Trapero Casas. 1999. 'Maalot' a new orchard-resistant cultivar to peacock eye leaf spot (Spilocaea oleagina Cast.). Olivae 78:51-59.

Mekuria, G.T., G.G. Collins, and M. Sedgley. 1999. Genetic variability between different accessions of some common commercial olive cultivars. J. Hort. Sci. Biotechnol. 74:309 314

Michelmore, R.W., I. Payon, and R.V. Kesseli. 1991. Identification of markers linked to disease resistance genes by bulked segregant analysis: A rapid method to detect markers in specific genomic regions by using segregating populations. Proc. Natl. Acad. Sci. USA 88:98289832.

Ogawa, J.M. and H. English. 1991. Diseases of temperate zone tree fruits and nut crops. Univ. of Calif., Division of Agr. and Natural Resources, Oakland, Calif. Publ. 3345.

Shabi, E., R. Birger, and S. Lavee. 1994. Leaf spot (Spilocaea oleaginea) of olive in Israel and its control. Acta Hort. 356:390-394.

Sutter, E.G. 1994. Olive cultivars and propagation, p. 23-25. In: L. Ferguson, G.S. Sibbett, and G. Martin (eds.). Olive production manual. Univ. of Calif., Division of Agr. and Natural Resources, Oakland, Calif. Publ. 3353

Teviotdale, B.L. 1994. Pest management: Diseases of olives, p. 107-109. In: L. Ferguson, G.S Sibbett, and G.C. Martin (eds.). Olive production manual. Univ. of Calif., Division of Agr. and Natural Resources, Oakland, Calif. Publ. 3353.

Warburton, M.L., V.L. Becerra-Velasquez, J.C. Goffreda, and F.A. Bliss. 1996. Utility of RAPD markers in identifying genetic linkages to genes of economic interest in peach. Theor. Appl. Genet. 93:920-925.

Wechter, W.P., M.P. Whitehead, C.E. Thomas, and R.A. Dean. 1995. Identification of a randomly amplified polymorphic DNA marker linked to the Fom 2 Fusarium wilt resistance gene in muskmelon MR-1. Phytopathology 85:1245-1249.

Weisman, Z., N. Avidan, S. Lavee, and B. Quebedeaux. 1998. Molecular characterization of common olive varieties in Israel and the West Bank using random amplified polymorphic DNA (RAPD) markers. J. Amer. Soc. Hort. Sci. 123:837-841.

Wirthensohn, M.G., G. Collins, G.P. Jones, and M. Sedgley. 1999. Variability in waxiness of Eucalyptus gunni foliage for floriculture. Scientia Hort. 82:279-288.

Yang, H. and J. Krüger. 1994. Identification of a RAPD marker linked to the $V f$ gene for scab resistance in apple. Plant Breeding 112:323-329. 